\title{
The stuff irony is made of: Translators as scholars
}

\section{Marella Feltrin-Morris}

Ithaca College

Though barely known in the United States, Achille Campanile (1900-1977) is considered one of Italy's major humorists of the twentieth century. In one of his most memorable short pieces entitled "La lettera di Ramesse" (Campanile, 1984), Campanile takes his cue from the traditional comedy of errors and gives it an original twist by setting it in ancient Egypt and creating a series of misunderstandings of a love letter written in hieroglyphics. He then tops it off by introducing a renowned scholar who, centuries later, discovers the message and publishes it in a highly acclaimed translation which, ironically, is yet another misinterpretation. This paper examines "Ramses's Letter" as a tongue-in-cheek commentary on interpretation and translation, a translation where subjectivity and desire prevail over content. It also discusses how, by rising to the empyrean of scholars, the translator becomes the target of the same irony that Campanile directs against all men of letters, and against writers in particular. Finally, since "Ramses's Letter" has never been available to an English-language audience, the paper features my own translation of the piece and a brief examination of the challenges I faced in approaching the ironical aspects of this text.

\section{Beyond translatability}

Much of the literature available on the translation of irony focuses on the difficulty of finding effective correspondents in the target culture that will produce the same - or at least similar - reactions in the target-language readers as the original did on the source-language readers (Bacchelli, 1991; Mateo, 1995; Pelsmaekers \& Van Besien, 2002). This is especially difficult in the case of puns and other humorous devices closely tied to language structures and sounds, but it is equally challenging when the irony is so ingrained in the source culture as to require a knowledge and understanding of it that is rarely found in a reader who is unfamiliar with the source language.

One of Umberto Eco's finest essays from Diario minimo, entitled "Elogio di Franti" (Eco, 1963), may serve as an example. Any Italian whose childhood was branded by the reading of Cuore (De Amicis, 1886/1987) would immediately recall Franti as the superbly evil child in Edmondo De Amicis's post-unification novel, in which the patriotic theme is infused with sentimentality and, in many passages, with an emphasis on moral values that, to contemporary readers, smacks of paternalism. Perhaps guessing that English-language readers would be unfamiliar with Cuore and the cultural connotations it carries, and therefore miss the irony in Eco's 
paean for the single champion of badness among the overwhelming goodness, "Elogio di Franti" was not included in Misreadings, the English version of Diario minimo (Eco, 1963/1993). ${ }^{1}$

The difficulty in conveying irony in translation might also explain why one of Italy's major humorists of the twentieth century, Achille Campanile, has barely been translated into English. Aside from The Inventor of the Horse and Two Other Short Plays (Campanile, 1971/1994), hardly any other translations can be found of his many works, and he remains virtually unknown in the United States. ${ }^{2}$ Indeed, Campanile's bravura passages such as "La quercia del Tasso" (Campanile, 1973b) or "La rivolta delle sette" (Campanile, 1973c) from Manuale di conversazione would bring any translator to their knees and both have been cited as examples in a study that discusses the concept of translation as adaptation (Henri, 2003, p. 196). ${ }^{3}$ Adaptation ${ }^{4}$ would represent the only way out for someone who were to undertake, out of passion or masochism, a translation of Campanile's wordplay.

For those who insist in treating translation merely in terms of loss and gain (although the gain is seldom acknowledged, even by the translators themselves), the loss of humor in the translation of a humorous text may well be regarded as an irreparable loss, the worst loss of all. Like a flower that loses its scent when carried from the field to a vase, nothing is more pathetic than a humorous text that, in translation, no longer stirs any laughter. The issue is one of communication, or rather, of partial communication: even when the message comes across, its comic effect has evaporated and, as happens when one attempts to save a joke by explaining it, any effort to squeeze laughter from an audience by poking at the flimsy substance of humor only serves to deflate it even more.

However, the goal of this paper is not to discuss the difficulty or the impossibility of translating humor or irony, but rather, to examine translation as a laughing matter, a field which, as it gains more visibility and respect among scholars and therefore comes to be regarded as an intellectual activity by experts and laymen alike, also becomes the target of the same sort of irony that is often directed, at least in Italy, towards all intellectual and artistic endeavors.

\section{Intellectuals as targets of irony}

A master in the craft of exposing the ridiculousness of affectation is, namely, Achille Campanile who, throughout his works, pokes fun at the clichés of language and at those who indulge in them without a hint of selfirony, those who, all engrossed in their role as bearers of knowledge or pioneers of art, fail to hear the snoring sound coming from their often unwilling audience. This is particularly visible in the many passages 
Campanile devotes to the art (or supposed art) of writing, to writers and storytellers, who are typically parodied in one of two ways.

The first way is as talentless dilettantes who occasionally achieve celebrity by accident or through people's gullibility. This is the case with the protagonist of the short story "La mestozia" (Campanile, 1973a, pp. 4148). ${ }^{5}$ Egidio, an utterly boring and predictable writer, is suddenly acclaimed by readers and critics alike when he hires an incompetent typist whose countless misspellings of his texts turn them into masterpieces of the comic genre. Thus, the "sweet melancholy" he dictates to his typist becomes a "sweet melangoly," which he proceeds to launch as a beauty product, making extraordinary profits. Needless to say, the goldmine ultimately exhausts itself when the typist decides to improve her skills and no longer misspells Egidio's texts. The last line of the short story grimly reads: "It was a catastrophe" (Campanile, 1973a, p. 48). Examining this rise and fall from the perspective of translation, one may say that the involuntary "translation" of the text into something that bears no relation to the original seems to be the guarantee for success. When the classic ideal of translation as perfect transparence is achieved (i.e. the text read exactly like the original), that marks the end of the writer's career. In Campanile's world of the absurd, lack of talent paired up with incompetence creates a literary phenomenon, and it is only when incompetence is replaced by professionalism that the fragile balance is upset, with disastrous results.

The second way in which Campanile parodies writers is by depicting them as authentic hoaxers, slackers who hide behind a semblance of intellectualism but who in reality are after an easy, carefree life of total idleness. This is a recurring theme in In campagna è un'altra cosa (Campanile, 1984). ${ }^{7}$ Nothing really happens in the novel: the protagonist and first-person narrator, Serenello - the name itself evokes not a writer or an intellectual, but a playful, breezy youth of scarce ambitions -, is a writer and journalist who decides to spend some time at his uncle's house in the countryside, ostensibly looking for inspiration, but actually determined to work as little as possible. Reflections on writing as a bogus occupation abound; one section entitled "The association I would like to found" describes a longed-for club that would draw together all those who want to do nothing: its members would hold periodic meetings with the goal of sharing all of the plans that were not accomplished and presenting proposals for projects that will not be pursued. Immediately following is a section entitled "Is writing a job?", where Serenello patiently lectures his domestic, Orazio. The latter regards the narrator's occupation with a mixture of suspicion and awe, and Serenello explains to him that, unlike the famous $18^{\text {th }}$-century writer Vittorio Alfieri, who had his own servant tie him to his desk so he would be forced to work, he only works until lunch is ready, which often happens to coincide, quite curiously, with the time he sits down to start working. A whole chapter of the book is devoted to providing Orazio, who in the meantime has decided to pursue a literary 
career, with tips on "How to write a novel." A revealing section with regards to this ironic instruction manual is Serenello's unabashed account of when, finding himself with three hundred pages to write and no ideas to write on, he decided to opt for a love story in which the male character stutters and, prompted by his beloved to declare his feelings for her, attempts to do so for about a hundred pages. At this point, with two hundred more pages to go, the writer had to resort to a more drastic strategy: he had the woman ask the stutterer to repeat his profession of love another thousand times.

\section{The irony of misinterpretation}

Campanile's representation of writers, which also functions as selfdeprecation, puts into question not only their abilities, but the honesty of their purpose, as well. This suspicion regarding writers is also directed toward scholars in general and, in a specific section of the book, even translators. ${ }^{8}$ The section again comes from In campagna è un'altra cosa (Campanile, 1984). It appears in a chapter dedicated to love letters, a very delicate subject, where reading between the lines is essential, and where a word alone can earn the writer access to the most sublime sensual bliss, or ban him forever from the arms of his beloved. As in many other works, Campanile draws irony out of the fallibility of language. Umberto Eco argues that "Campanile's play on words lucidly condemns language and its emptiness" (Eco, 1998, p. 70). ${ }^{9}$ However, "emptiness" is perhaps not the appropriate term: it is not at the emptiness of language that Campanile pokes fun, but at its slippery nature. One register suddenly disappears into another; there is constant interference of other voices, the awkward but not completely unpleasant awareness of one's own voice, and the necessity to reflect on it. This metalanguage is often close to that of Luigi Pirandello, but without the bitterness that usually accompanies Pirandello's musings. Yes, Campanile is fully convinced of the fragility of communication, but he joyfully exploits it, revealing the extent to which communication is impaired by one's own desires, the desires of the speaker, of the writer, and even of the translator. In this piece, called "Ramses's Letter" (Campanile, 1984, pp. 169-179), Campanile uses, as his starting point, the ancient Egyptians' use of hieroglyphics as means of communication. ${ }^{10}$ The assumption is that such language is ambiguous and subject to all kinds of interpretation, especially when in the hands of a less-than-skilled writer who is blinded by love to boot. Thus, when young Ramses decides to write a love letter to a girl despite his scarce drawing skills, readers already know they are in for a series of hilarious misinterpretations of the message. Even more comical is the gap between the clarity of the message in the writer's mind and the unavoidable step of making it ambiguous by having to translate it into cryptic signs: "He ran home, ordered a papyrus, and set out 
to scribble down his declaration of love, all the while cursing against the Egyptians' odd way of writing, which forced a lousy artist like him to express himself by means of stick figures." What follows is the text of his message accompanied by Campanile's own drawings.

If on the one hand the desire to win the girl's love does not translate itself into a beautiful and effective message (i.e. good intentions do not make a good writer), on the other, the girl's quick temper does not help matters and, instead, contributes to the misinterpretation of the message. She therefore misinterprets Ramses's "Lovely maiden" as "You abominable cripple," and "If you are not insensitive to the arrows of my love" as "bodywise, you look rather like a fishbone." Campanile often intentionally mixes up different registers of language, and this is no exception. Here he also makes use of anachronisms for comic effect, and as a result, the wideopen eye that was meant to convey "from the first moment I saw you" is interpreted as "I just ate a fried egg." Analogously, the kneeling figure meant to suggest respect and admiration becomes "Enough for now, I need to shine my shoes." It is again desire that leads Ramses to misread the girl's angry response and interpret it in turn as a sign of requited love. Thus, "you are a useless bullock" turns into "I think we could find a cozy little place near the temple of the sacred bull, Apis," and "I will punch you" becomes "I shall give you my hand."

If so far misinterpretation was unintentional and its consequences remained limited to the individual writer and reader, the last part of "Ramses's Letter" brings a "scholar" into the scene, and therefore makes a bolder statement on the appraisal and diffusion of culture and, indirectly, on translation. It is interesting to notice that here Campanile reverts to the flowery and lyrical language register he had used at the beginning of the story and then abandoned during the description of the exchanges between the two lovers. Those exchanges included very colloquial expressions and insults, while now a solemn tone returns:

Quattromila anni sono passati. Il papiro di Ramesse è stato tratto alla luce da un grande egittologo, il quale dopo due lustri di profondissimi studi è riuscito a ridare all'ammirazione degli uomini il brano di sublime poesia contenuto in esso. (Campanile, 1984, p.177)

Four thousand years have gone by. Ramses' papyrus has been recovered by a great Egyptologist who, after two lustra of intense study, has succeeded in rendering the sublime poetry it contains for all humanity to admire. (my translation)

The irony here is not produced by a surprise effect: readers can easily guess that what follows will be yet another misinterpretation. It is however the debunking of the myth of the learned scholar that causes laughter, much like many jokes about the wise man on the mountain who turns out to be no 
wiser than those who climb up to hear his precious advice. This is already evident in the choice of words that describe the scholar and his work: "a great Egyptologist," "after two lustra of intense study," "the sublime poetry it contains," "for all humanity to admire." 11 In this sense, the last part represents the desire for revenge on the part of readers of obscure texts who are forced to rely on the expertise of scholars and/or translators. Here, the situation is somewhat reversed: readers are the ones "in the know." They have been present during the composition of the text, and have already enjoyed a sense of superiority during the misunderstanding between the two young Egyptians. Now they are even in the privileged position of being able to recognize and judge the incompetence or, worse, the dishonesty, of the "great Egyptologist." The scholar/translator fails to see (or refuses to see) the text for what it is - an example of miscommunication. Instead, recognizing only one of the signs (the god Anubis), not only does he transform the text, but he recreates it, forcing all of the other signs to fit his interpretation. Not by chance, although his work claims to be a "full-text translation," a part has been eliminated (the crossed-out image of Anubis).

We are in the presence of what Umberto Eco called, in his 1965 essay entitled "Towards a semiotic enquiry into the television message," "aberrant decoding" (Eco, 2003, p. 4), in which, through the passing of time and in the hands of a reader who, despite his extensive studies, has no relation with the source culture, the message has taken on a meaning that the authors could never have foreseen. If the misinterpretation between the two Egyptians could easily have been clarified (but was not, because for Campanile communication is no more effective than it is for Pirandello), the same cannot be said about the scholar, whose interest seems to be that of creating art out of the very same lack of talent that had caused the misinterpretation in the first place. The incentive to do so is not very different from that which had prompted the young Egyptian to write his letter, and it is the oldest incentive of all: desire. The desire to express one's love and to be loved in return, alongside the desire to bask in the author's reflected glory, no matter whether the text is worthwhile or not.

We are miles away from a concept of translation as fidelity to a text. What fidelity? If one takes the elusiveness of language to its extreme, Campanile seems to suggest, the rule of thumb becomes instinct, and misinterpretation looms as a constant risk (or temptation) over laymen and scholars alike, with the aggravating side effect that the latter present themselves as the voice of authority. What is fascinating in "Ramses's Letter" is the fact that, precisely because they do not demand to be accepted as truths, the young Egyptians' misinterpretations of each other's messages sound much more genuine than the renowned scholar's stuffy distortion of the text. And his claim to have grasped the one and only essence of the text is emphasized by the term Campanile uses to indicate him: "the scientist." The debate on whether translation can be regarded as a science or an art is still wide open, but by labelling the Egyptologist/translator as a "scientist" - 
in this context, one who has found the key to unveil the mystery of the text -, Campanile has hit one of the most sensitive issues of translation: the translator's desire, not only to reach the truth of the message, but also to render it in its only possible form. But if the message, as in this case, was ambiguous in the first place, such desire can never be fulfilled, and those who insist on posing as the bearers of the only truth end up just like the other would-be intellectuals who populate the pages of In campagna $\grave{e}$ un'altra cosa, that is, as fodder for Campanile's irony.

\section{On translating Campanile}

Unlike many of Campanile's stories, "Ramses's Letter" does not rely heavily on wordplay, thus no particularly creative solutions were needed in order to preserve the ironic effect. However, much of the irony in it is based on change of register, and therefore, in order to prepare the ground for the two young people's colorful exchange, it was essential to reproduce the sophisticated, formal language of the initial description. This is why I opted for poetic constructions such as "Sweet was the night" and "There rose a soft chant." I also chose to maintain a characteristic of Campanile's humor, namely, the surreal escalation of absurdity in his writing, which in this story he carries out by switching register seemingly at random. As a result, Ramses's lack of control of his artistic skills extends to his linguistic abilities as well, and the deferential tone he wishes to convey becomes, by the end of his letter, oddly bureaucratic. Hence the use of a legalistic expression such as "in strict compliance with the law" ("con perfetta osservanza").

The girl's misinterpretation of the love message as a letter of insult, on the other hand, required a colloquial language that would immediately elicit her outraged reaction, and for this reason I occasionally traded fidelity for the sake of effect, as in the case of "un'oca perfetta" which I translated as "a silly goose." A more challenging term was "beccaccione," which is a typical insult in the Roman dialect (Campanile was originally from Rome) meaning "a gullible person" but also "a cuckold." term that would contain the meaning of "cuckold" while fitting at the same time the picture of a horned animal yielded no satisfactory results. However, further reflection led me to conclude that, in Italian, this expression, as well as the more common one of "cornuto" (lit. "horned one") ${ }^{13}$, function as generic insults, not to be interpreted literally, but rather, as accusations of inadequacy. Therefore, I redirected my search towards an expression that would convey the notion of uselessness, ideally without losing the sexual connotation and still matching the image of the horned animal. The solution I finally chose was "bullock," which in its second definition means "a castrated bull" 14 and thus retains the attack to a man's virility, while still working with the picture. In order to emphasize the 
notion of ineffectiveness even further, I added the adjective "useless." As for historical or geographical (in)accuracies, I intentionally accentuated Campanile's surreal situational irony by translating a colloquial invective such as "Mascalzone" with "What a skunk!", which introduces yet another extraneous element - an animal that is native to the Americas - to the hodgepodge of incongruities in the story.

Finally, in order to underscore the contrast between the young man's romantic language, the girl's fiery response, and the Egyptologist's pompous, academic style, I translated the latter using archaisms such as "thou art," "thee," and "shalt." Indirectly, Campanile's ironic treatment of the scholar's language parodies translations of ancient texts that desperately attempt to recapture the flavor of a bygone era, often with ludicrous results. Hopefully, the stilted expressions I have chosen in my own translation manage to achieve a similar effect.

\section{Achille Campanile "Ramses's Letter"" 15}

Sweet was the night on the banks of the sacred Nile. The colors of the sunset lingered on the water, which glimmered and quivered through the palm trees behind Anubis's temple. There rose a soft chant of priests. Then all was silent.

Ramses was walking, lost in thought. The solitude of the place, which seemed made for lovers' encounters, increased his melancholy. Couples slipped by through the shadows, not far from him. He alone did not have a partner. It was there that he had seen her for the first time a few days earlier, and since then he had come back every night as if on a loving pilgrimage, hoping to find her again and declare his feelings for her. But the girl had not reappeared. "I love her," the young Egyptian sighed. "I love her passionately. But how can I let her know? Ah, yes: I'll write her a letter." $\mathrm{He}$ ran home, ordered a papyrus, and set out to scribble down his declaration of love, all the while cursing against the Egyptians' odd way of writing, which forced a lousy artist like him to express himself by means of stick figures.

"I am pleased to see you have embraced painting," said his father when he saw him at work.

"I haven't. I'm writing a letter," explained Ramses.

And, full of zeal, he resumed his work.

"I will say to her," he mused, "Lovely maiden..." 
(And he drew a maiden, trying to make her as lovely as possible).

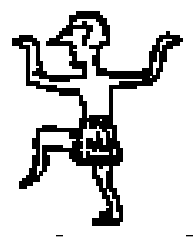

...from the first moment I saw you... (He tried to draw a wide-open eye full of passion).

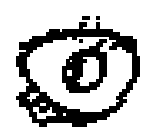

...my thoughts have been flying out to you... (How to express this poetic concept? That's it: he drew a bird on the papyrus).

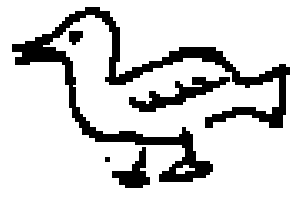

...If you are not insensitive to the arrows of my love... (He drew a shooting arrow).

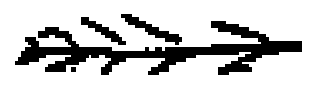

...please come in seven months' time... (Seven little moons lined up on the papyrus).

\section{6}


...right where the sacred Nile bends...(This was very easy: the lovestruck youth had simply to trace a zigzagging river).

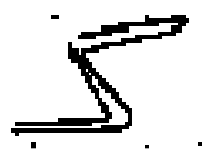

... and precisely next to Anubis's temple... (This too was rather easy, since the image of the god with a man's body and a dog's face was familiar to everyone).

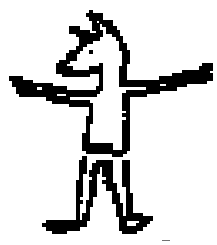

...so as to allow me to express my respectful admiration for you... (He drew himself kneeling down).

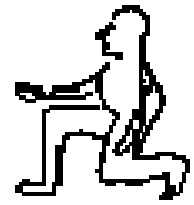

...In faith, and in strict compliance with the law, etc.

Having reached the end of his arduous task, the young and resourceful Egyptian handed the letter to his servant:

"Take it to Psammetichus's daughter," he said. "It's urgent."

"Oh," exclaimed the old illiterate. "What a pretty spy glass!"

"It's a papyrus, idiot. Bring me back her answer."

$$
* * *
$$

Soon afterwards, Psammetichus's lovely daughter was busy deciphering young Ramses's mediocre drawings, and interpreted them as follows: 
You abominable cripple...

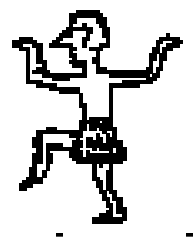

I just ate a fried egg...

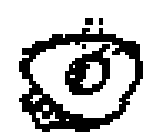

...уои are a silly goose...

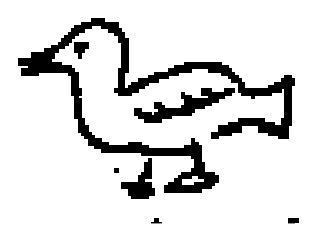

...but, bodywise, you look rather like a fishbone... ${ }^{16}$

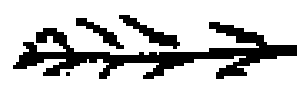

I will pelt you with stones...

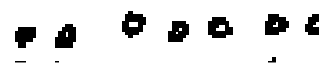

You are a filthy little worm...

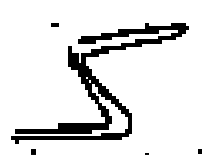


...and you can use Anubis's protection... mummies!")

("What a skunk!", thought the girl. "Anubis is the patron of

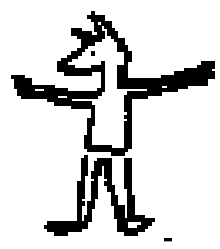

...Enough for now, I need to shine my shoes.

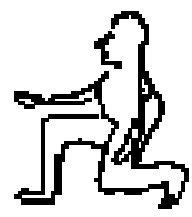

Greetings, etc.

("You miserable coward," screamed the girl. "Now I'll fix you!" She grabbed the stylus and, below the same letter, she wrote:

If I am a goose...

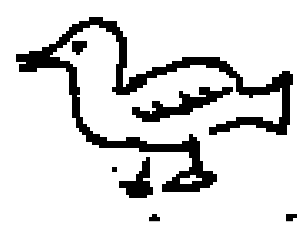

...though by no means a mummy...

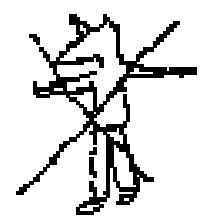


...you are a useless bullock...

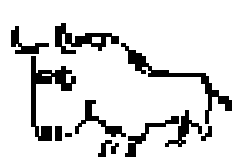

... and I will punch you.

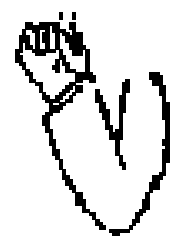

She expressed the whole sentence by drawing very carefully a goose, a crossed-out image of Anubis, a horned animal, and a closed fist.

She handed the letter to Ramses's servant, who returned to his master.

Imagine the latter's joy when, once again because of his scarce artistic abilities, he deciphered the girl's hieroglyphics as follows:

My thoughts also fly constantly out to you...

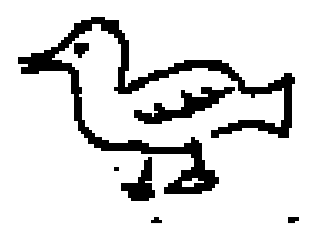

...but I believe it would be unwise to meet by Anubis's temple...

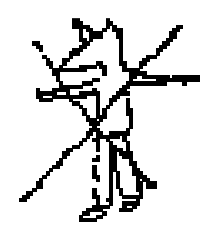


...instead I think we could find a cozy little place near the temple of the sacred bull, Apis...

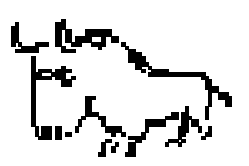

...where I shall give you my hand.

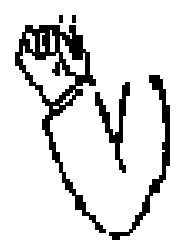

$* * *$

Four thousand years have gone by. Ramses's papyrus has been recovered by a brilliant Egyptologist who, after two lustra of intense study, has succeeded in rendering the sublime poetry it contains for all humanity to admire. Here it is, in the full-text translation done by the scholar:

O thou Osiris who art wearily dancing

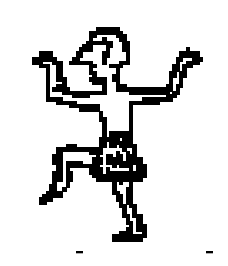

on the lotus flower,

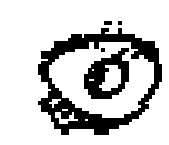


followed by Ibis, thy sacred bird,

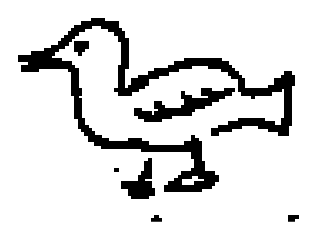

to thee I offer this ear of wheat

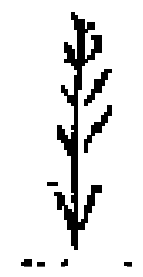

and seven tiny beans, freshly shelled,

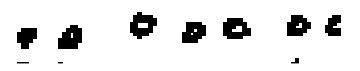

begging thee to keep from me the slithering lure of envy,

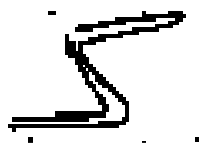

while to the supreme Anubis,

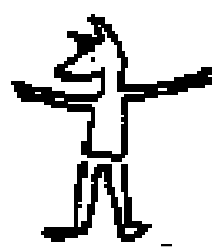


before whom I prostrate myself,

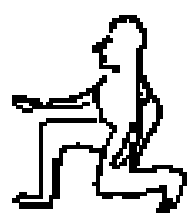

followed in turn by the sacred Ibis,

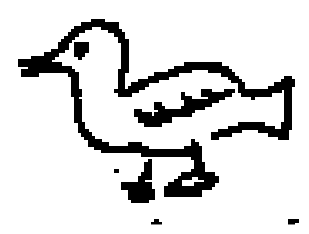

I sacrifice a fatted calf

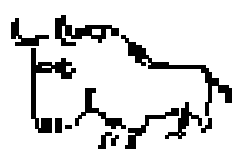

that I shalt kill with my own fist.

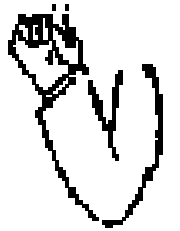




\section{References}

\section{Primary source}

Campanile, A. (1984). In campagna è un'altra cosa (c'è più gusto). (1st ed.). Milan: BUR.

\section{Secondary sources}

Baker, M. (Ed.). (1998). Routledge encyclopedia of translation studies. London: Routledge.

Campanile, A. (1973a). La mestozia. In Manuale di conversazione (pp. 41-48). Milan: Rizzoli.

Campanile, A. (1973b). La quercia del tasso. In Manuale di conversazione (pp. 105107). Milan: Rizzoli.

Campanile, A. (1973b). La rivolta delle sette. In Manuale di conversazione (pp. 295297). Milan: Rizzoli.

Campanile, A. (1985). "Lord Brummel, or how NOT to get noticed." E. Scalia (Translated into English. Italian original "Lord Brummel, o del non farsi notare", 1975). The literary review, 28(2), 218-219.

Campanile, A. (1994). The inventor of the horse and two other short plays. F. Loriggio (Translated into English. Italian original L'inventore del cavallo e altre quindici commedie, 1971). Toronto: Guernica.

Cuddon, J.A. (1992). Penguin's dictionary of literary terms and literary theory. ( $\left.3^{\text {rd }} \mathrm{ed}.\right)$. New York: Penguin Books.

De Amicis, E. (1886). Cuore. Milan, Treves.

De Amicis, E. (1887). Cuore, an Italian schoolboy's journal: A book for boys. I. Hapgood (Translated into English. Italian original Cuore, 1886). New York: Cromwell.

Eco, U. (1963). Diario minimo. Milan: Mondadori.

Eco, U. (2003). Towards a semiotic enquiry into the television message. In T. Miller (Ed.), Television: critical concepts in media and cultural studies, vol. 2 (pp. 219). London: Routledge.

Eco, U. Misreadings (1993). W. Weaver (Translated into English. Italian original Diario minimo, 1963). San Diego: Harcourt Brace \& Co.

Eco, U. (1998). Tra menzogna e ironia. Milan: Bompiani.

Freud, S. (1993). Wit and its relation to the unconscious. A.A. Brill (Translated into English. German original Der Witz und seine Beziehung zum Unbewussten. 1905). New York: Dover Publications.

Henri, J. (2003). La traduction des jeux de mots. Paris: Presses de la Sorbonne Nouvelle. Mateo, M. (1995). The translation of irony. Meta: journal des traducteurs / Meta: translators' journal, 40(1), 171-178. 
Pelsmaekers, K. and Van Besien, F. (2002). Subtitling irony. The translator, 8(2), 241266.

Russo Bacchelli, R. (1991, January-December). The double meaning of meaning: Humorous writing and its translatability. International journal of translation 3(1-2), 98-103.

Słapek, D. (2009). "Acqua minerale" cioè come tradurre i giochi di parole di Achille Campanile. Romanica silesiana 4, 231-43.

1 Interestingly enough, another culturally loaded essay, "Fenomenologia di Mike Bongiorno" ("The Phenomenology of Mike Bongiorno"), which is dedicated to Italy's most renowned and most often parodied television host, is featured in Misreadings and its inclusion is explained with the fact that, "while unknown to non-Italians, [Mike Bongiorno] belongs to a familiar, international category" (Eco, 1993, p. 3).

2 An exception is the piece entitled "Lord Brummel, or how NOT to get noticed" (Campanile, 1985, pp. 218-219).

3 Another recent article dealing with the challenge of translating Campanile's humor is Słapek, D. 'Acqua minerale' cioè come tradurre i giochi di parole di Achille Campanile (Słapek, 2009).

4 "Adaptation may be understood as a set of translative operations which result in a text that is not accepted as a translation but is nevertheless recognized as representing the source text of about the same length" (Baker, 1998, p. 5).

5 The title is a distortion of "mestizia," "melancholy," which could be rendered in English through a made-up word such as "melangoly."

6 My translation.

7 "Out in the Country It's a Different Story." The title itself is a cliché, the mark of bad writers and of a sterile imagination. The trite Italian expression "è un'altra cosa" ("it's a different story") is typically accompanied by a sigh, in an attempt to lament the loss or the absence of a better time/space/situation without specifying what it was that made it better.

8 The section in question is entirely built on an issue of misunderstanding of the message, therefore I will be making constant reference to interpretation - one of the necessary steps for translation. While interpretation does not necessarily equal translation because it does not always produce a tangible version of the text, translation is always interpretation, and as such, it is bound to be subjective.

9 My translation.

10 The misinterpretation of hieroglyphics, or of smoke signals within the Native American context, has been a staple source of jokes in countless Italian comic strips. 
11 This last section of "Ramses's Letter" is the most purely ironic, according to Freud's definition of irony: "The essence of irony consists in imparting the very opposite of what one intended to express, but it precludes the anticipated contradiction by indicating through the inflections, concomitant gestures, and through slight changes in style - if it is done in writing - that the speaker himself means to convey the opposite of what he says" (Freud, 1993, pp. 276-77). If in the correspondence between the man and the woman the misinterpretation was mostly conveyed humorously, the hyperbolic depiction of the scholar as an expert is instead ironic, as his translation turns out to be everything but accurate, and thus belies the expectations that had been set forth when his character was introduced. It matters very little that most readers would not take those expectations seriously: irony stems here from "the perception or awareness of a discrepancy or incongruity between words and their meaning" (Cuddon, 1992, p. 460). In the rest of the story, on the other hand, the discrepancy occurs between "actions and their results" (Cuddon, 1992, p. 460): Ramses's misunderstood attempt to express his love to the girl results in her angry response, which in turn produces an unwanted effect (i.e. his conviction that she loves him back).

12 This explains the horned animal, the horns being traditionally associated with infidelity, as the cuckolded husband wears horns (i.e. the mark of infidelity) that can be seen by everyone but him.

13 Often directed at referees during soccer games.

14 The other option was "steer" which, however, sounded too technical and had the disadvantage of too many additional meanings.

15 Permission to publish is gratefully acknowledged to Gaetano Campanile.

16 Indeed, Ramses's arrow had not come out very well. 